\title{
New data on the occurrence of terrestrial true bugs (Hemiptera: Heteroptera) in Pieniny Mountains
}

\author{
Artur TASZAKOWSKI and Agnieszka PASIŃSKA \\ Department of Zoology, Faculty of Biology and Environmental Protection, University of Silesia, Bankowa 9, 40-007 \\ Katowice, Poland; e-mail: ataszakowski@us.edu.pl
}

\begin{abstract}
The results on studies of the fauna of true bugs are presented. The research was conducted in the years 2005-2008 in the Pieniny Mountains. A list of 71 species, mainly belonging to the family Miridae, is presented. Among the identified specimens such rare species in Poland as Eurycolpus flaveolus, Stenodema sericans and Berytinus signoreti deserve a special interest. Features that distinguish very similar species, such as Lygus wagneri and L. punctatus, are given.
\end{abstract}

Key words: true bugs, new records, Poland, faunistics, rare species, Pieniny National Park

\section{INTRODUCTION}

Fauna of Pieniny Mts is characterized by conspicuous richness and diversity. This is the result of location within the bend of the Carpathians, vicinity of the mountains of a different character, the terrain topography which facilitates migration, low altitude, limestone substratum and specific microclimate. The absence of the ice cover in the Pleistocene was an important factor too (Razowski 2000). The Pieniny Mts are characterized by great ecological and geographical differentiation and this seems to be the most important feature of these mountains. On a small area there occur plants and animals species with different ecological demands and origins, and thus thermophilous and montane species occur side by side (Razowski 2000).

The true bugs of the Pieniny Mts are relatively poorly known. The data on Heteroptera of this region comes mainly from old works (Nowicki 1868; Lomnicki 1882; Stobiecki 1915; Smreczyński 1907, 1954). More recent faunistic data were presented in reviews (Lis B. 1996; Lis J. A. 1989a, b, 1990; Stroiński 2001) of selected families or in materials relating to the distribution of selected taxa (Skórka 1995, Lis J.A. 1988, Lis B. 2001, Lis B. \& Lis J.A. 2009, Hebda \& Ścibior 2016). In 2013 a species new for the country, Gampsocoris culicinus Seidenstücker, 1948, was found in Pieniny Mts (Hebda \& Ścibior 2013), and in 2016 new data on the distribution of 30 species were presented (Hebda \& Ścibior 2016).

\section{STUDY AREA AND METHODS}

The present studies were conducted at 16 sites located in the area of Pieniny National Park, within two UTM (Universal Transverse Mercator) grid zones: [DV57] - Czerniawa, Forędówka, Kąty, Kotłowy Stream, Magierowa Rock, Marcelowy Ravine, Podłaźce Clearing, Podskalnia Mountain, Stodolisko Clearing, Stolarzówka Clearing, Szopczański Ravine, Szopka Pass, Toporzysko, Wyrobek Clearing, Za Kocioł Ravine, Wielkie Załonie; [DV67] - Kras. Material was collected in years 2005 - 2008 by A. Pasińska. The specimens are preserved in the collection of Department of Zoology UŚ. 
Color photographs were obtained using the following equipment: Leica M205C (stereomicroscope), Leica DFC495 (camera), Leica application suite 4.9.0 (software). Specimens for SEM analysis were prepared using a method modified from that of Kanturski et al. (2015, 2017) and were imaged with a Phenom XL field emission scanning electron microscope. Graphic processing was done in a free graphic application Paint.NET, in which also maps were prepared.

\section{RESULTS}

Details of the collecting place and date are omitted for the most frequently collected species (more than 20 individuals) on more than 5 sites. New species for the region are marked with an asterisk $\left(^{*}\right)$.

Cimicomorpha Leston, Pendergrast et Southwood, 1954

Cimicoidea Latreille, 1802

Anthocoridae Fieber, 1836

Anthocorinae Fieber, 1836

*Anthocoris nemoralis (Fabricius, 1774)

Szopka Pass, 12 Aug 2005, 1 ex.

\section{Anthocoris nemorum (Linnaeus, 1761)}

Stolarzówka Clearing, 16 Jun 2006, 2 exx.

Nabidae Costa, 1853

Nabinae Costa, 1853

*Himacerus apterus (Fabricius, 1798)

Podłaźce Clearing, 17 Jun 2006, 1 ex. Szopka Pass, 18 Aug 2007, 1 ex.

*Himacerus mirmicoides (O. Costa, 1834)

Kotłowy Stream, 13 Aug 2005, 1 ex. Kras, 15 Aug 2007, 3 exx. Marcelowy Ravine, 21 Aug 2007, 1 ex. Szopka Pass, 15 Jun 2006, 1 ex.; 18 Aug 2007, 2 exx.

\section{*Nabis brevis Scholtz, 1847}

Throughout the study area collected in large numbers.

\section{Nabis flavomarginatus Scholtz, 1847}

Throughout the study area collected in large numbers.

Nabis limbatus Dahlbom, 1851

Podłaźce Clearing, 17 Jun 2006, 1 ex.; 20 Aug 2007, 2 exx.; 27 Jun 2007, 1 ex. Stolarzówka Clearing, 16 Jun 2006, 2 exx.; 19 Aug 2006, 1 ex. Szopka Pass, 18 Aug 2007, 2 exx.

Nabis rugosus (Linnaeus, 1758)

Kotłowy Stream, 17 Aug 2005, 2 exx. 
*Nabis pseudoferus Remane, 1949

Kras, 15 Aug 2007, 1 ex. Marcelowy Ravine, 19 Aug 2007, 1 ex. Podłaźce Clearing, 20 Aug 2007, 1 ex. Szopka Pass, 18 Aug 2007, 2 exx. Wielkie Załonie, 14 Aug 2007, 3 exx.

Miroidea Hahn, 1831

Miridae Hahn, 1833

Bryocorinae Baerensprung, 1860

Bryocoris pteridis (Fallén, 1807)

Stolarzówka Clearing, 23 Aug 2008, 5 exx.

\section{Dicyphus globulifer (Fallén, 1829)}

Marcelowy Ravine, 20 Aug 2008, 1 ex. Podłaźce Clearing, 1 Jul 2007, 1 ex.; 6 Jul 2007, 3 exx. Wielkie Załonie, 14 Aug 2007, 1 ex.

\section{Dicyphus pallidus (Herrich-Schäeffer, 1836)}

Stolarzówka Clearing, 23 Aug 2008, 5 exx.

Dicyphus stachydis Sahlberg J.R., 1878

Kotłowy Stream, 15 Jun 2006, 3 exx.

Monalocoris filicis (Linnaeus, 1758)

Stolarzówka Clearing, 23 Aug 2008, 8 exx.

Deraeocorinae Douglas et Scott, 1865

*Deraeocoris ruber (Linnaeus, 1758)

Kąty, 19 Aug 2005, 1 ex. Kotłowy Stream, 27 Jun 2007, 2 exx. Podłaźce Clearing, 27 Jun 2007, 3 exx.; 1 Jul 2007, 2 exx.; 6 Jul 2007, 3 exx.

Orthotylinae Van Duzee, 1916

Globiceps flavomaculatus (Fabricius, 1794)

Kąty, 19 Aug 2005, 1 ex. Kotłowy Stream, 20 Aug 2005, 2 exx.; 17 Aug 2006, 3 exx.

Halticus apterus (Linnaeus, 1761)

Throughout the study area collected in large numbers.

\section{Heterocordylus tumidicornis (Herrich-Schäeffer, 1835)}

Marcelowy Ravine, 29 Jun 2007, 1 ex.

\section{Orthocephalus brevis (Panzer, 1798)}

Podłaźce Clearing, 14 Jun 2006, 3 exx.; 17 Jun 2006, 1 ex. Stolarzówka Clearing, 19 Jun 2006, 3 exx. Szopka Pass, 18 Aug 2006, 1 ex. Wyrobek Clearing, 1 Jul 2005, 1 ex.

\section{Phylinae Douglas et Scott, 1876}

\section{*Chlamydatus pulicarius (Fallén, 1807)}

Kras, 18 Aug 2008, 2 exx. Stolarzówka Clearing, 23 Jun 2008, 1 ex. Szopka Pass, 18 Aug 2007, 1 ex. 
*Chlamydatus pullus (Reuter, 1870)

Szopczański Ravine, 17 Jun 2006, 1 ex.

\section{*Criocoris crassicornis (Hahn, 1834)}

Kotłowy Stream, 20 Aug 2005, 1 ex. Podłaźce Clearing, 27 Jun 2007, 1 ex.

\section{Criocoris nigripes Fieber, 1861}

Szopka Pass, 15 Jun 2006, 1 ex.; 23 Jun 2008, 1 ex.

\section{Europiella alpina (Reuter, 1875)}

Podłaźce Clearing, 20 Aug 2007, 1 ex. Podskalnia Mountain, 20 Aug 2008, 1 ex. Szopka Pass, 18 Aug 2007, 1 ex.

\section{Eurycolpus flaveolus (Stål, 1858)}

Kotłowy Stream, 20 Aug 2005, 1 ex. Marcelowy Ravine, 16 Aug 2005, 1 ex. Podłaźce Clearing, 19 Aug 2006, 1 ex.; 06 Jul 2007, 1 ex.

Remarks: Species known from European countries, northern and north-western territories of China, Georgia, Kirgizia, Mongolia, East Siberia and the Far East of Russia (Kerzhner \& Josifov 1999). In Poland extremely rare, reported so far only from Pieniny Mts (vicinity of Krościenko), where 11 individuals were collected in 1910 (Smreczyński 1954, Gorczyca 1991). Earlier it was also found somewhere in "Galicja" (Gorczyca 1991, 2004b). Because it is a very characteristically and contrastingly colored insect (Fig. 1), oversight by entomologists seems unlikely. Individuals of this species prefer sunny and thermophilic grasslands. Adults feed on plants of genus Bupleurum L., and are exclusively macropterous. It overwinters as an egg, and has one generation per year (Gorczyca 2004a).
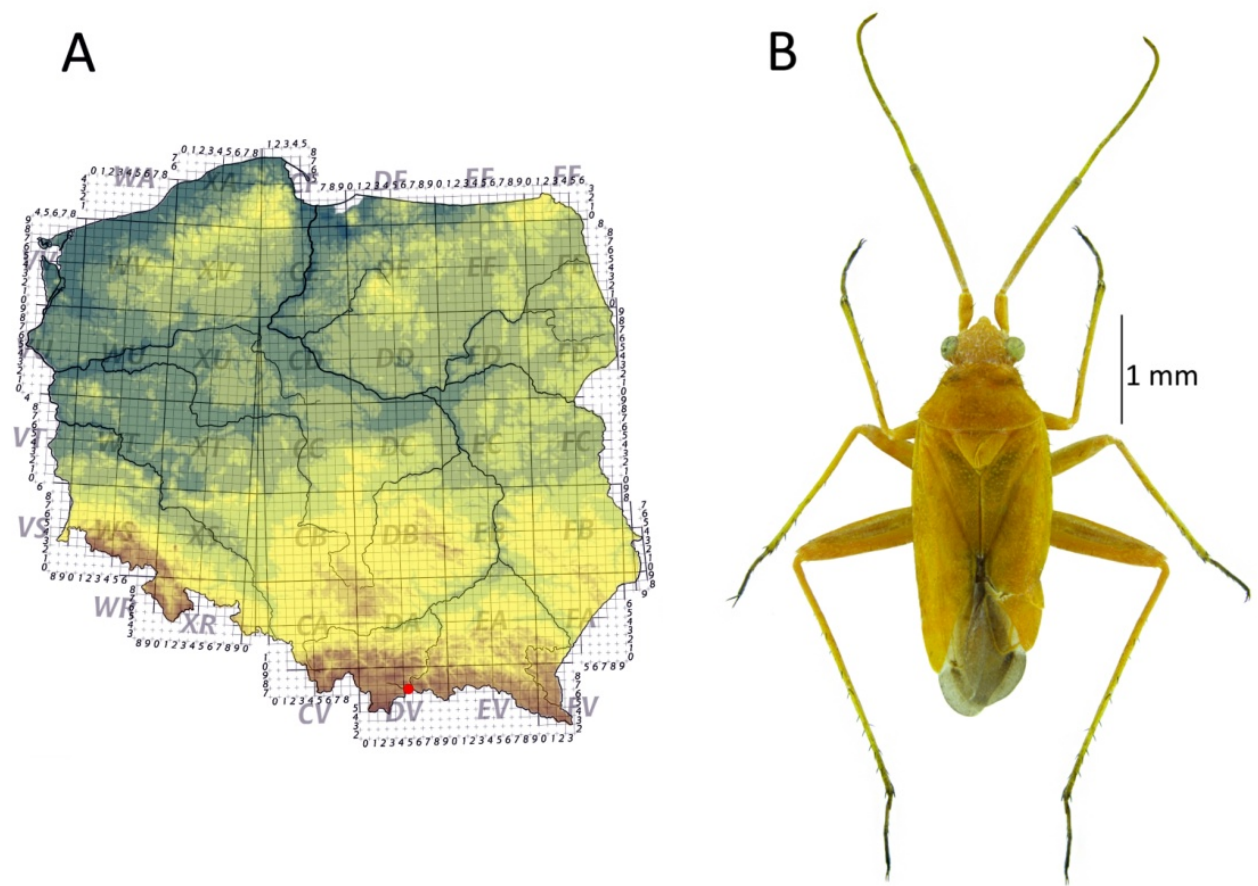

Fig. 1. Eurycolpus flaveolus: A - Distribution in Poland; - - confirmed data; B - dorsal habitus. Photo by A. Taszakowski 
*Macrotylus paykullii (Fallén, 1807)

Marcelowy Ravine, 16 Aug 2005, 1 ex. Podłaźce Clearing, 6 Jun 2007, 3 exx.

Macrotylus quadrilineatus (Schrank, 1758)

Kotłowy Stream, 14 Aug 2006, 3 exx. Kras, 15 Aug 2007, 3 exx. Podłaźce Clearing, 20 Aug 2007, 1 ex. Szopczański Ravine, 15 Jun 2006, 1 ex. Szopka Pass, 18 Aug 2006, 2 exx. Wielkie Załonie, 14 Aug 2007, 1 ex.

\section{*Orthonotus rufifrons (Fallén, 1807)}

Podłaźce Clearing, 1 Jul 2007, 2 exx. Wyrobek Clearing, 28 Jun 2007, 1 ex.; 19 Aug 2005, $1 \mathrm{ex}$.

*Placochilus seladonicus (Fallén, 1807)

Kras, 24 Jun 2008, 1 ex. Podłaźce Clearing, 27 Jun 2007, 1 ex. Wyrobek Clearing, 19 Aug 2005, 1 ex. Za Kocioł Ravine, 17 Aug 2005, 1 ex.

\section{*Plagiognathus arbustorum (Fabricius, 1794)}

Kras, 14 Aug 2007, 2 exx. Marcelowy Ravine, 4 Jul 2007, 1 ex. Podłaźce Clearing, 27 Jun 2007, 3 exx. Stodolisko Clearing, 21 May 2005, 1 ex. Stolarzówka Clearing, 12 Aug 2005, 1 ex.; 23 Aug 2008, 1 ex.

*Plagiognathus chrysanthemi (Wolff, 1804)

Throughout the study area collected in large numbers.

Mirinae Hahn, 1833

Adelphocoris detritus (Fieber, 1861)

Stolarzówka Clearing, 19 Aug 2006, 1 ex.

*Adelphocoris lineolatus (Goeze, 1778)

Kotłowy Stream, 15 Aug 2006, 1 ex.

Adelphocoris quadripunctatus (Fabricius, 1794)

Stolarzówka Clearing, 19 Aug 2006, 1 ex. Kras, 18 Aug 2008, 3 exx.

Adelphocoris seticornis (Fabricius, 1775)

Throughout the study area collected in large numbers.

*Apolygus lucorum (Mayer-Dür, 1843)

Podłaźce Clearing, 19 Aug 2006, 1 ex.; 6 Jul 2007, 1 ex. Szopka Pass, 16 Aug 2006, 1 ex. Kotłowy Stream, 15 Aug 2006, 1 ex.

\section{Calocoris affinis (Herrich-Schäeffer, 1835)}

Throughout the study area collected in large numbers.

\section{Capsus ater (Linnaeus, 1758)}

Szopka Pass, 18 Aug 2006, 3 exx. Podłaźce Clearing, 17 Jun 2006, 2 exx.; 27 Jun 2007, 3 exx.; 1 Jul 2007, 1 ex. Stolarzówka Clearing, 5 Jul 2005, 1 ex. Marcelowy Ravine, 16 Aug 2005, 2 exx. Szopczański Ravine, 8 Aug 2005, 1 ex.

\section{Charagochilus gyllenhalii (Fallén, 1807)}

Marcelowy Ravine, 1 May 2008, 1 ex.; 20 Aug 2008, 1 ex. Szopka Pass, 15 Jun 2006, 1 ex. Podłaźce Clearing, 20 Jul 2007, 1 ex.; 27 Jun 2007, 1 ex. Kras, 14 Aug 2007, 1 ex. Kotłowy Stream, 15 Aug 2006, 1 ex.; 17 Aug 2005, 1 ex. 


\section{Leptopterna dolabrata (Linnaeus, 1758)}

Throughout the study area collected in large numbers.

\section{Lygus pratensis (Linnaeus, 1758)}

Throughout the study area collected in large numbers.

\section{*Lygus rugulipennis Poppius, 1911}

Throughout the study area collected in large numbers.

\section{*Lygus wagneri Remane, 1955}

Throughout the study area collected in large numbers.

Remarks: Specimens of the genus Lygus were collected in large numbers. Identification of $L$. pratensis and $L$. rugulipennis is not problematic, but L. wagneri and Lygus punctatus (Zetterstedt, 1838) are difficult to distinguish from each other. These species have similar coloration, which is characterized also by very high variability. The differences in structure of paramers, which used by Wagner \& Weber (1964), were not included as distinguishing taxonomic features in the most recent revision of Palearctic species of the genus Lygus (Aglyamzyanov 2009). The shape of vesical spicula, which clearly distinguishes species within the genus, in this case is a little valuable feature, because it is very similar in both species (Fig. 2A, B). The puncturation of the corium (Fig. 2C) is the only reliable feature that distinguishes both species (Aglyamzyanov 2009):

L. punctatus - puncturation of the corium is scattered and uneven, distance of punctures from each other on clavus is clearly shorter than on the middle of corium;

L. wagneri - puncturation of the corium is dense and uniform, distance of points from each other on clavus is the same as on the middle of corium (Fig. 2C).

This feature is poorly visible in the light microscope, therefore the photographs taken on a scanning electron microscope are most useful.

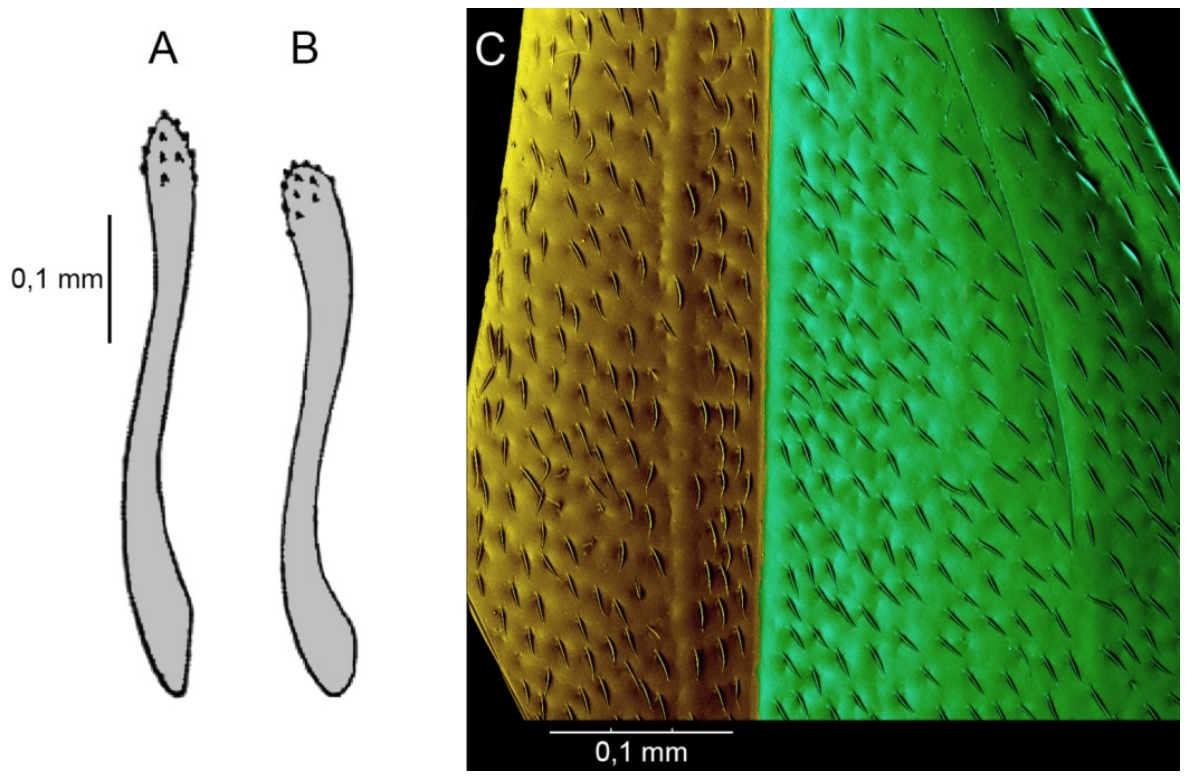

Fig. 2. The distinguishing features of L. wagneri and L. punctatus. A - spiculum of vesica of L. wagneri; B - spiculum of vesica of L. punctatus, according Aglyamzyanov (2009), modified.; C - Structure of the middle part of right corium L. wagneri: yellow - clavus, green - corium (photo by A. Taszakowski \& M. Kanturski). 
* Notostira erratica (Linnaeus, 1758)

Podłaźce Clearing, 20 Aug 2007, 4 exx.; 14 Aug 2005, 1 ex. Kras, 14 Aug 2007, 1 ex. Stolarzówka Clearing, 19 Jun 2006, 1 ex. Wielkie Załonie, 14 Aug 2007, 1 ex.

*Notostira elongata (Geoffroy, 1785)

Szopka Pass, 5 Jun 2005, 1 ex. Wielkie Załonie, 14 Aug 2007, 1 ex. Wyrobek Clearing, 1 Jul 2005, 1 ex.

\section{*Orthops basalis (A. Costa, 1853)}

Marcelowy Ravine, 4 Jul 2007, 1 ex.

*Polymerus nigrita (Fallén, 1807)

Kotłowy Stream, 21 Aug 2005, 1 ex. Podłaźce Clearing, 1 Jul 2007, 1 ex. Toporzysko, 28 Jun 2005, 1 ex.

*Polymerus palustris (Reuter, 1907)

Throughout the study area collected in large numbers.

\section{Polymerus unifasciatus (Fabricius, 1794)}

Podłaźce Clearing, 27 Jun 2007, 1 ex. Kotłowy Stream, 27 Jun 2007, 1 ex.

\section{*Stenodema calcarata (Fallén, 1807)}

Kras, 15 Aug 2007, 1 ex. Stolarzówka Clearing, 16 Jun 2006, 1 ex. Podłaźce Clearing, 6 Jul 2007, 1 ex; 20 Aug 2007, 1 ex.

\section{Stenodema holsata (Fabricius, 1787)}

Throughout the study area collected in large numbers.

Stenodema laevigata (Linnaeus, 1758)

Stolarzówka Clearing, 5 Jun 2005, 2 exx.

\section{Stenodema sericans (Fieber 1861)}

Kras, 15 Aug 2007, 1 q. Kotłowy Stream, 14 Aug 2006, 1 ઈ.

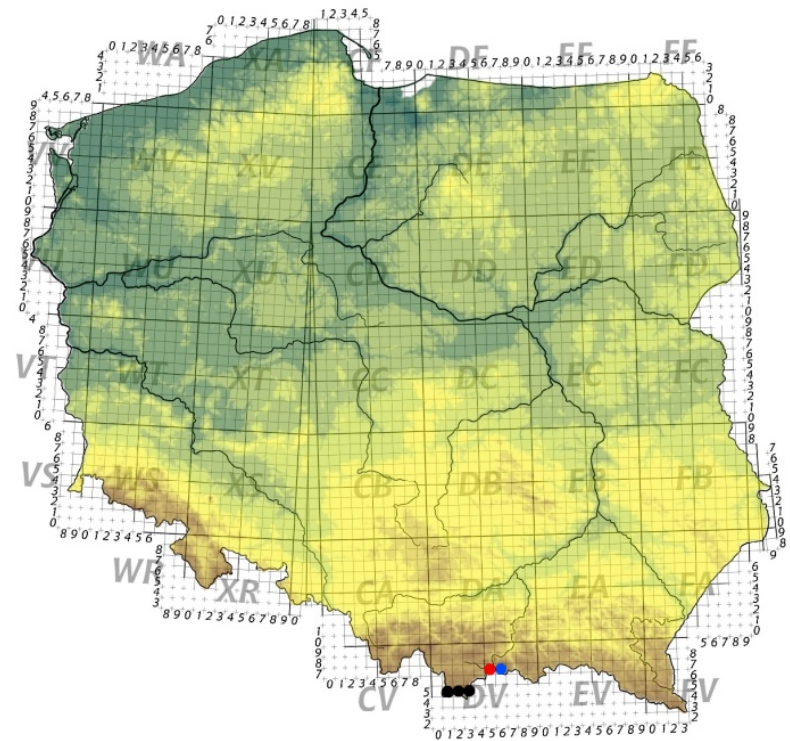

Fig. 3. Distribution of Stenodema sericans in Poland; $\bullet$ - literature data, $\bullet$ - confirmed data, $\bullet-$ new data. 
Remarks: The species inhabits the mountains in southern Europe from the Pyrenees over the Alps to the Carpathians and the Balkans. S. sericans lives in the valleys, alpine dwarf shrubs and alpine grasslands (Wachmann et al. 2004). Occurs on Poaceae, but trophic relationships are poorly known. In Poland extremely rare (Fig. 3), known only from Pieniny and Tatra Mountains (Gorczyca \& Wolski 2011). Overwinters as an adult on conifers and plant of the family Ericaceae, a new generation adults appear in July (Wachmann et al. 2004).

Among the Polish species of the genus, $S$. sericans is most similar to $S$. holsata. The easiest way to distinguish them is based on the length of the first segments of the antennae, which are distinctly longer in S. sericans than in S. holsata (Fig. 4).
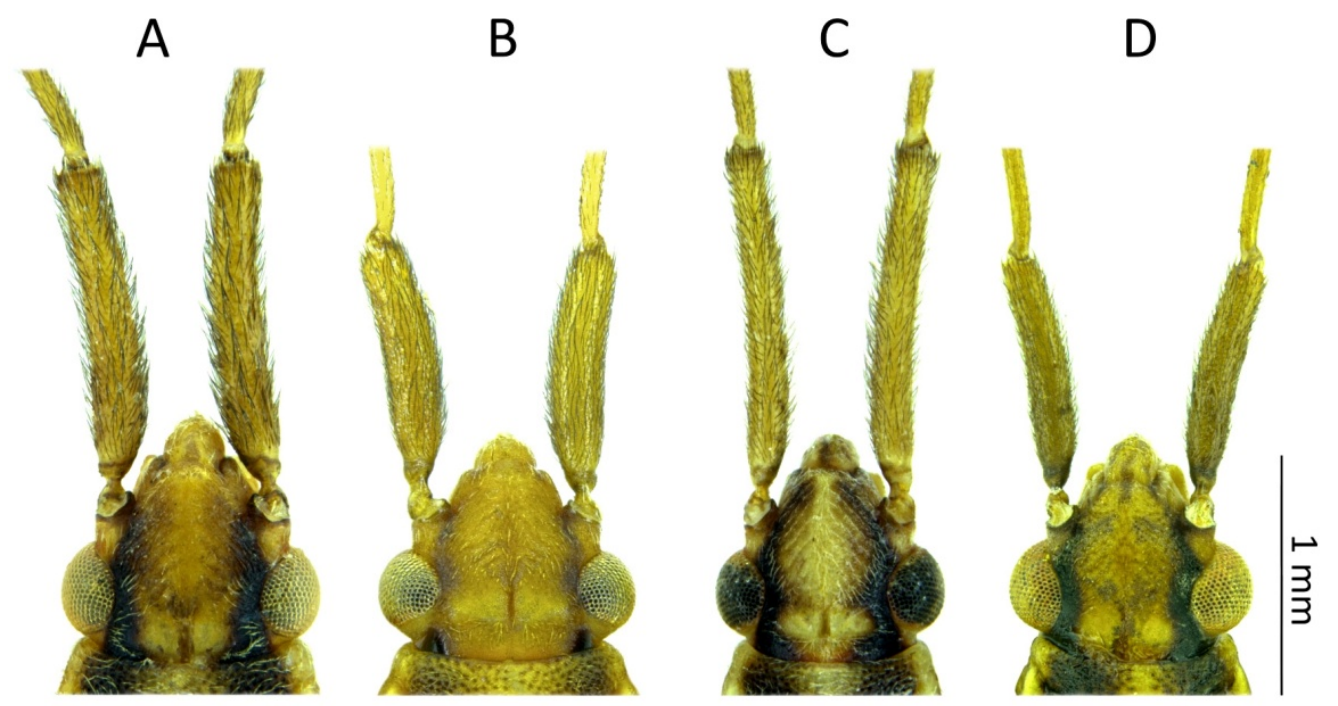

Fig. 4. Comparison of Stenodema sericans and Stenodema holsata: A - S. sericans, female, B - S. holsata, female, C S. sericans, male, $\mathbf{D}-\mathrm{S}$. holsata, male. Photo by A. Taszakowski.

\section{*Trigonotylus caelestialium (Kirkaldy, 1902)}

Kras, 18 Aug 2006, 3 exx. Podłaźce Clearing, 20 Aug 2007, 3 exx. Podskalnia Mountain, 22 Aug 2008, 1 ex. Marcelowy Ravine, 19 Aug 2007, 1 ex.

Tingoidea Laporte, 1832

Tingidae Laporte, 1832

Tinginae Laporte, 1832

\section{Derephysia foliacea (Fallén, 1807)}

Marcelowy Ravine, 29 Jun 2007, 1 ex. Kotłowy Stream, 27 Jun 2007, 1 ex. Podłaźce Clearing, 27 Jun 2007, 2 exx.; 1 Jul 2007, 1 ex.

*Dictyla humuli (Fabricius, 1794)

Podłaźce Clearing, 6 Jul 2007, 1 ex. Wielkie Załonie14, Aug 2007, 1 ex.

\section{*Tingis ampliata (Herrich-Schäeffer, 1838)}

Podłaźce Clearing, 17 Jun 2006, 2 exx.; 27 Jun 2007, 1 ex. Stolarzówka Clearing, 16 Jun 2006, 1 ex. Marcelowy Ravine, 1 May 2008, 1 ex. 
Tingis cardui (Linnaeus, 1758)

Kras, 14 Aug 2007, 1 ex. Marcelowy Ravine, 20 Aug 2008, 1 ex.

Pentatomomorpha Leston et al., 1954

Coreoidea Leach, 1815

Rhopalidae Amyot et Serville, 1843

*Myrmus miriformis (Fallén, 1807)

Podłaźce Clearing, 20 Aug 2007, 4 exx. Kras, 15 Aug 2007, 3 exx.

*Rhopalus maculatus (Fieber, 1837)

Podłaźce Clearing, 20 Aug 2007, 1 ex. Forędówka, 17 Aug 2008, 2 exx.

*Rhopalus parumpunctatus Schilling, 1829

Stolarzówka Clearing, 19 Aug 2008, 2 exx. Kras, 15 Aug 2007, 2 exx. Szopka Pass, 18 Aug 2007, 2 exx.; 16 Aug 2006, 2 exx. Podłaźce Clearing, 20 Aug 2007, 6 exx.

Rhopalus subrufus (Gmelin, 1790)

Throughout the study area collected in large numbers.

*Stictopleurus punctatonervosus (Goeze, 1778)

Podłaźce Clearing, 20 Aug 2007, 2 exx. Marcelowy Ravine, 21 Aug 2007, 2 exx.

Lygaeoidea Schilling, 1829

Berytidae Fieber, 1851

Berytinae Fieber, 1851

Berytinus clavipes (Fabricius, 1794)

Kras, 14 Aug 2007, 1 ex.; 18 Aug 2008, 1 ex. Marcelowy Ravine, 22 Jun 2008, 1 ex. Kotłowy Stream, 15 Jun 2006, 1 ex.; 15 Aug 2006, 1 ex. Podłaźce Clearing, 27 Jun 2007, 1 ex.; 17 Jun 2006, 1 ex.; 19 Aug 2006, 1 ex.

Podłaźce Clearing, 1 Jul 2007, 1 ex.

\section{Berytinus crassipes (Herrich-Schäeffer, 1835)}

*Berytinus minor (Herrich-Schäeffer, 1835)

Podłaźce Clearing, 17 Jun 2006, 1 ex.

\section{Berytinus signoreti (Fieber, 1859)}

(Fig. 5)

Kras, 18 Aug 2008, 1 ex.

It occurs in western and northern Europe, in Poland rarely collected, known for a dozen sites in the south part of the country (Lis B. 2007). Xerophilous species, occurs on sandy or limestone soils, on dunes, and in dry clearings (Péricart 1984, Lis B. 2007). Among others, the following host plants are given: Lotus corniculatus, Ononis, Hippocrepis, Medicago and Thymus. B. signoreti is univoltine species and overwinters as adult (Lis B. 2007, Wachmann et al. 2007). 


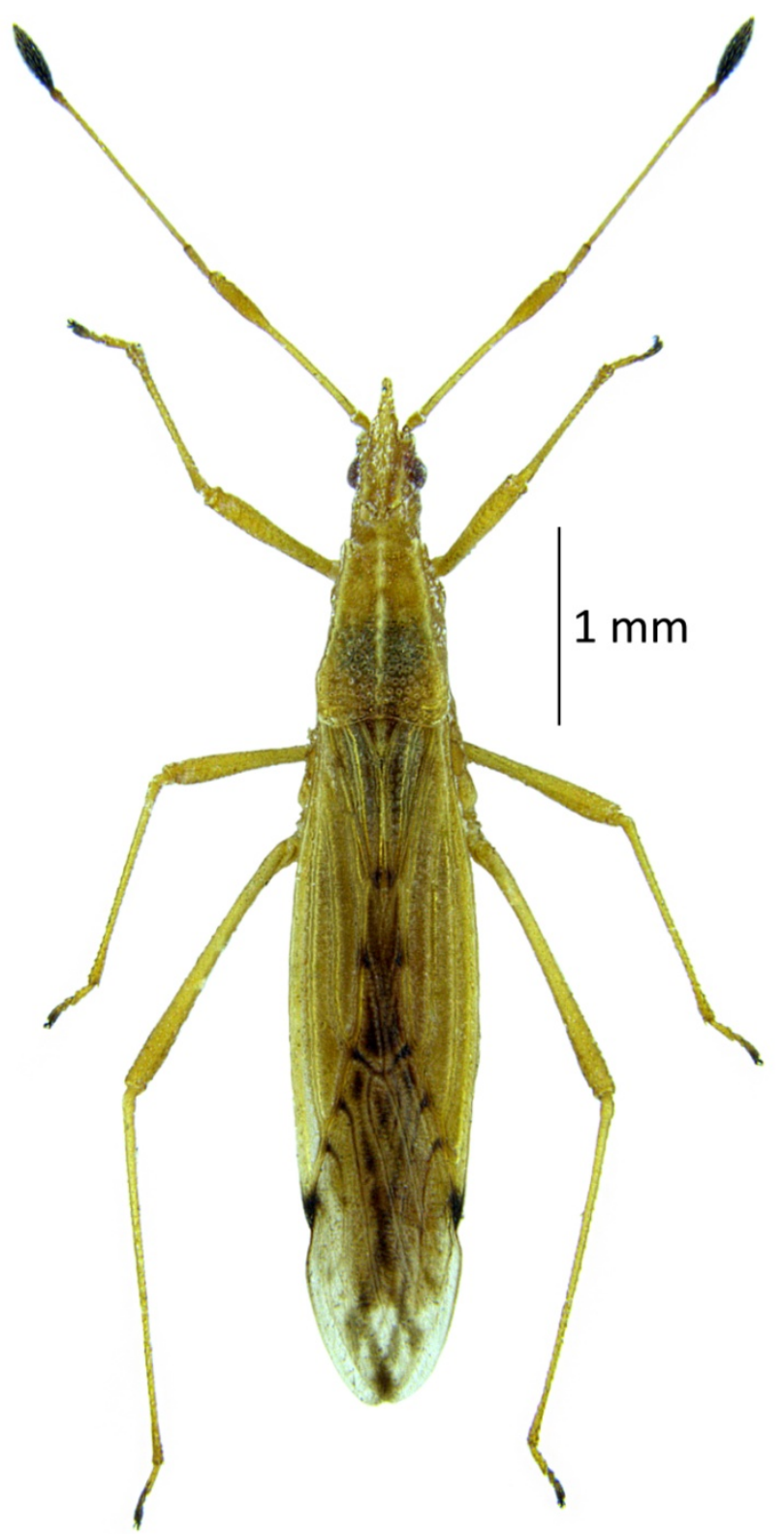

Fig. 5. Berytinus signoreti. Photo by A. Taszakowski.

*Neides tipularius (Linnaeus, 1758)

Kras, 14 Aug 2007, 1 ex.

Gampsocorinae Southwood \& Leston, 1959

Gampsocoris punctipes (Germar, 1822)

Throughout the study area collected in large numbers. 
Rhyparochromidae Amyot et Serville, 1843

Rhyparochrominae Amyot et Serville, 1843

*Stygnocoris sabulosus (Schilling, 1829)

Kras, 15 Aug 2007, 1 ex.

Pentatomoidea Leach, 1815

Scutelleridae Leach, 1815

Eurygastrinae Amyot et Serville, 1843

Eurygaster testudinaria (Geoffroy, 1785)

Throughout the study area collected in large numbers.

\section{SUMMARY AND DISCUSSION}

In the research area a total number of 71 species of Heteroptera were collected. They proved to belong to 8 different families: Anthocoridae (2 species), Nabidae (7 species), Miridae (45 species), Tingidae (4 species), Rhopalidae (5 species), Berytidae (6 species), Rhyparochromidae (1 species) and Scutelleridae (1 species). Almost half of them, 34 species, were recorded for the first time in Pieniny Mts. First records of very common Polish species in the study area (e.g. Deraeocoris ruber, Chlamydatus pulicarius, Criocoris crassicornis, Plagiognathus arbustorum, P. chrysanthemi, Lygus rugulipennis and Stenodema calcarata) (Gorczyca 2007, Gorczyca \& Wolski 2011) prove the still insufficient knowledge of the heteropterofauna of Pieniny Mts. It should be noted that some of these species were probably previously collected on the area of Pieniny Mts, but due to their commonality, the authors did not provide detailed data on their collecting sites, e.g. Smreczyński (1954).

A

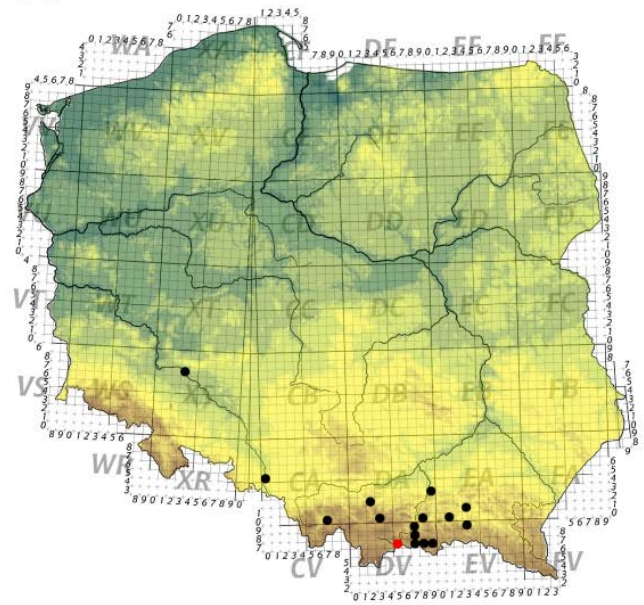

B

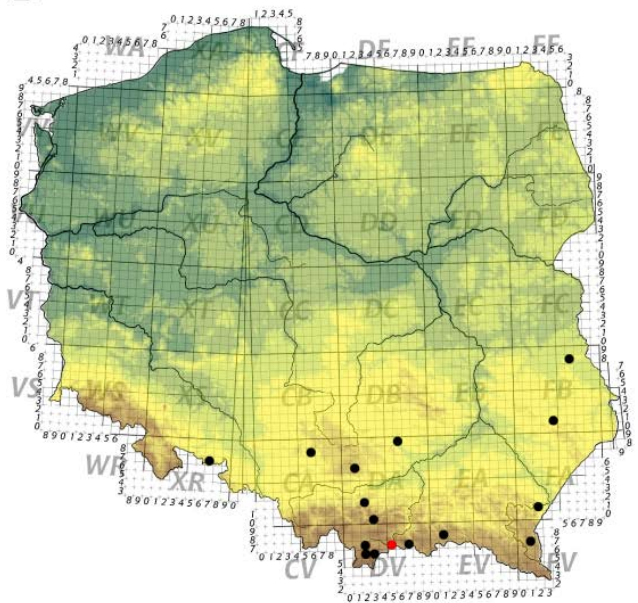

Fig. 6. Distribution of Adelphocoris detritus (A) and Criocoris nigripes (B) in Poland; • - literature data, $\bullet$ - confirmed data.

Some of the recorded true-bugs are rarely collected in Poland: e.g. thermophilic species of southern type of range (Adelphocoris detritus: Fig. 6A, Criocoris nigripes: Fig. 6B, Eurycolpus flaveolus and Berytinus signoreti), as well as mountain species (Macrotylus quadrilineatus, 
Stenodema sericans, Berytinus signoreti and Lygus wagneri) (Gorczyca 2007, Gorczyca \& Wolski 2011, Taszakowski 2016). Occurrence of thermophilic species of southern type of range in Pieniny Mts may be associated with an immigration via the Spisz migratory route. During the immigration, the habitats that formed on the warm slopes of the valley of the Dunajec River could be used (Mazur 2001, Taszakowski 2015).

A notable species is Eurycolpus flaveolus, which has not been recorded since 1910. In Poland it is known exclusively from Pieniny Mts. The species was included in the Polish Red book of animals, with the status "probably extinct" (Gorczyca 2004b).

\section{ACKNOWLEDGEMENTS}

We are greatly indebted to Dr Mariusz Kanturski (Silesian University, Department of Zoology) for assistance in the preparation of photos with scanning electron microscope.

\section{REFERENCES}

Aglyamzyanov R.S. 2009. Revision of the Palaearctic species of Lygus Hahn, 1833 (Heteroptera: Miridae). Entomologische Zeitschrift mit Insekten-Börse, 119 (6): 249-276.

Gorczyca J. 1991. Phylinae (Heteroptera, Miridae) of Poland. Annals of the Upper Silesian Museum in Bytom, Entomology 2: 17-81.

GorczyCA J. 2004a. Tasznikowate - Miridae. Podrodzina Phylinae. Klucze do oznaczania owadów Polski, 18 (6b): 183.

GorCZYCA J. 2004b. Eurycolpus flaveolus (Stäl, 1858). In: GŁOWACIŃSKi Z. \& NowACKi J. (eds), Polish Red Data Book of Animals. Ivertebrates, p. 75. Instytut Ochrony Przyrody PAN, Akademia Rolnicza im. A. Cieszkowskiego, Kraków - Poznań, 447 pp.

Gorczyca J. 2007. Plant bugs (Heteroptera: Miridae) of Poland. Part I. Subfamilies Isometopinae, Deraeocorinae, Bryocorinae, Orthotylinae, Phylinae. Catalogus faunae Poloniae, Warszawa, 216 pp.

GorCZYCA J. \& WolSKI A. 2011. Plant bugs (Heteroptera: Miridae) of Poland. Part II. Subfamily Mirinae. Catalogus faunae Poloniae, Warszawa, $172 \mathrm{pp}$.

HeBDA G. \& ŚCIBIOR R. 2013. Gampsocoris culicinus Seidenstücker, 1948, species new to the Polish fauna (Heteroptera: Berytidae: Gampsocorinae). Genus 24 (1): 29-32.

HebDA G. \& ŚCIBIOR R. 2016. Nowe stanowiska pluskwiaków różnoskrzydłych (Hemiptera: Heteroptera) w Pieninach. Parki Narodowe i Rezerwaty Przyrody 35 (4): 93-98.

KANTURSKi M., KARCZ J. \& WIECZOREK K. 2015. Morphology of the European species of the aphid genus Eulachnus (Hemiptera: Aphididae: Lachninae) - a SEM comparative and integrative study. Micron 76: 23-36.

KANTURSKi M., Ali AKBar S. \& FAVRet C. 2017. Morphology and sensilla of the enigmatic Bhutan pine aphid Pseudessigella brachychaeta Hille Ris Lambers (Hemiptera: Aphididae) - a SEM study. Zoologischer Anzeiger A Journal of Comparative Zoology 266: 1-13.

Kerzhner I.A. \& Josifov M. 1999. Cimicomorpha II, Miridae. Volume 3. In: Aukema B. \& Rieger Ch. (eds). Catalogue of the Heteroptera of the Palaearctic Region. The Netherlands Entomological Society, Wageningen, XIV+577 pp.

LIS B. 1996. Tingidae of Poland - a faunistic review (Hemiptera: Heteroptera). Annals of the Upper Silesian Museum in Bytom, Entomology 6-7: 253-298.

LIS B. 2001. Nowe stanowiska rzadkich w faunie Polski gatunków pluskwiaków różnoskrzydłych (Hemiptera: Heteroptera). Przegląd Zoologiczny 45 (1-2): 89-93.

Lis B. 2007. Płaszczyńcowate - Piesmatidae, smukleńcowate - Berytidae, kowalowate - Pyrrhocoridae. Klucze do oznaczania owadów Polski 18 (9): 1-28.

LIS B. \& LIS J. A. 2009. Nowe stanowiska Heteroptera z uwagami taksonomicznymi oraz nowymi danymi o biologii wybranych gatunków. I. Aradoidea, Coreoidea, Pentatomoidea. Heteroptera Poloniae - Acta Faunistica 1: 1-49.

LIS J. A. 1988. Nowe stanowiska Lygaeus simulans Deckert, 1985 (Heteroptera, Lygaeidae) w Polsce. Przegląd Zoologiczny 32 (2): 207-209.

LIS J. A. 1989a. Shield-bugs of Poland (Heteroptera, Pentatomoidea) - a faunistic review. I. Plataspidae, Thyreocoridae, Scutelleridae and Acanthosomatidae. Polskie Pismo Entomologiczne 59: 27-83.

LIS J.A. 1989b. A review of the Polish Dipsocoromorpha (Heteroptera, Euheteroptera). Annals of the Upper Silesian Museum in Bytom, Natural History 12: 6165.

LIS J.A. 1990. Shield-bugs of Poland (Heteroptera, Pentatomoidea) - a faunistic review. Pentatomidae. Annals of the Upper Silesian Museum, Entomology 1: 5-102.

ŁoMNICKI M. 1882. Pluskwy różnoskrzydłe (Hemiptera-Heteroptera) znane dotychczas z Galicyi. Sprawozdania Komisyi Fizyograficznej PAU 16: 37-55. 
MAzUR S. 2001. Ryjkowce kserotermiczne Polski: (Coleoptera: Nemonichidae, Attelabidae, Apionidae, Curculionidae). Studium zoogeograficzne. Monografie Fauny Polski 22: 1-378.

NowICKI M. 1868. Wykaz pluskwówek (Rhynchota F. Hemipt.). Sprawozdania Komisyi Fizyograficznej PAU 2: 91-107. PERICART J. 1984. Hémiptères Berytidae euro-méditerranéens. Faune de France 70: 118-137.

RAZOWSKI J. 2000. Charakterystyka flory i fauny Pienin. In: RAzowsKi J. (eds), Flora i fauna Pienin. Monografie Pienińskie 1: 11-21.

SKóRKA S. 1995. Nowe stanowiska Lygaeus simulans Deckert, 1985 (Heteroptera: Lygaeidae) w Polsce. Acta Entomologica Silesiana 3: 35.

SMRECZYŃSKI S. 1907. Zbiór pluskwiaków Prof. Dra Stanisława Zaręcznego. Sprawozdania Komisyi Fizyograficznej PAU 40: 46-71.

SMRECZYŃSKI S. 1954. Materiały do fauny pluskwiaków (Hemiptera) Polski. Fragmenta Faunistica 7(1): 1-146.

STOBIECKI S. 1915. Wykaz pluskwiaków (Rhynchota) zebranych w Galicyi zachodniej i środkowej. Sprawozdania Komisyi Fizyograficznej PAU 49: 126-219.

StroiŃSKi A. 2001. A faunistic review of Polish species of the superfamily Coreoidea (Hemiptera: Heteroptera). Annals of the Upper Silesian Museum in Bytom, Entomology 10-11: 63-120.

TAsZAKowsKi A. 2015. Notes on the occurrence of Gampsocoris Fuss, 1852 (Hemiptera: Heteroptera: Berytidae) in Poland. Fragmenta Faunistica 58 (1): 1-6.

TASZAKOWSKI A. 2016. Lądowe pluskwiaki różnoskrzydłe (Hemiptera: Heteroptera) Beskidu Wschodniego - geneza fauny. Manuscript: Ph.D. dissertation. Department of Zoology, University of Silesia in Katowice.

Wachmann E., Melber A. \& Deckert J. 2004. Wanzen. Band 2. Cimicomorpha: Microphysidae (Flechtenwanzen), Miridae (Weichwanzen). Die Tierwelt Deutschlands 75, Goecke \& Evers, Keltern, 288 pp.

Wachmann E., Melber, A. \& Deckert J. 2007. Wanzen. Band 3. Pentatomomorpha I. Aradidae, Lygaeidae, Piesmatidae, Berytidae, Pyrrhocoridae, Alydidae, Coreidae, Rhopalidae, Stenocephalidae. Pp. 186-189. Die Tierwelt Deutschlands 78, Goecker \& Evers, Keltern.

WAgner E. \& Weber H. H. 1964. Hétéroptères Miridae. Faune de France. 67. Fédération Française Des Sociétés De Sciences Naturelles Office Central De Faunistique, Paris, 589 pp.

\section{STRESZCZENIE}

\section{[Nowe dane o występowaniu lądowych pluskwiaków różnoskrzydłych (Hemiptera: Heteroptera) w Pieninach]}

Lądowe pluskwiaki różnoskrzydłe na terenie Pienin są stosunkowo słabo poznane, a informacje o ich występowaniu pochodzą głównie z pierwszej połowy XX wieku. Niniejsza praca zawiera listę 71 gatunków Heteroptera, które zostały stwierdzone w czasie badań prowadzonych na obszarze Pienińskiego Parku Narodowego w latach 2005-2008. Część odłowionych Heteroptera jest stosunkowo rzadko spotykana w Polsce np. ciepłolubne gatunki o południowym typie zasięgu (Criocoris nigripes, Adelphocoris detritus, Eurycolpus flaveolus i Berytinus signoreti), jak również przedstawiciele górskiej heteropterofauny: Macrotylus quadrilineatus, Stenodema sericans, Berytinus signoreti i Lygus wagneri). Na szczególną uwage zasługuje Eurycolpus flaveolus, figurujący w Polskiej Czerwonej Księdze Zwierząt, znany w Polsce tylko z Pienin, wcześniej odławiany w 1910 roku. 